\title{
Regulatory issues and industrial policy in football'
}

\author{
Jonathan Michie and Christine Oughton
}

\section{Introduction}

The peculiar economics of professional sports leagues has long been recognised (see Neale, 1964). Traditionally, the essence of the problem was seen to lie in the fact that sports leagues and the individual clubs that make up the league provide a joint product that depends on effective co-operation between competing clubs. Clubs agree to join, and be regulated by, a league because co-operation in the supply of a joint product increases the economic value of the product supplied by each individual club. The output of the league and its constituent members is maximised when there is some degree of competitive balance in the league so that the outcomes of matches are uncertain. If leagues become unbalanced, lack of uncertainty over the outcomes of matches reduces demand by spectators/viewers. In the absence of regulation, leagues have a tendency to become unbalanced. Leading clubs attract more spectators and viewers, sell more merchandise and can command higher prices for tickets and for the rights to broadcast matches. Those revenues can be reinvested in players, which serves to maintain and enhance the dominance of the leading clubs. In the absence of measures to check those forces, leagues tend to become unbalanced, attract sub-optimal levels of spectators/viewers and face the dual threat of the bankruptcy that plagues lagging clubs and the possibility that breakaway groups of leading clubs will seek the competitive balance afforded by a rival league. For that reason most leagues play a regulatory role by redistributing income from stronger to weaker teams (Findlay, Holahan and Oughton, 1999).

More recently, two further peculiarities of professional football leagues have become apparent. The first concerns the nature and role of match-going supporters in the production of live football matches and issues in corporate governance, while the second concerns the vertical production relationship between football clubs and, on the one hand, the league and, on the other, television broadcasters.

In the UK, football, the largest professional league sport, has traditionally been regulated by the Football Association, the Football League and more recently the Premier League. In recent years the economic problems facing 
sports leagues have increased as the growth of pay-TV has opened up a new market for viewing sport that has significantly increased the revenue streams flowing into the game. As the commercialisation of professional sports leagues has increased, government has intervened with the Football Task Force, and there have been regulatory interventions from the Restrictive Practices Court and the Monopolies and Mergers Commission. At the same time, many football clubs have become plcs and in doing so have bypassed the key FA regulation against the commercial exploitation of clubs by gaining FA agreement that the newly created plc holding companies would be exempt from rule 34 which had, up until that time, prevented the owners of clubs from extracting profits. This change in the corporate governance of football clubs has heightened conflict between the various stakeholders match-going supporters, TV viewers, shareholders and managers. ${ }^{2}$

The institutional arrangements around the creation and development of the market for professional football in Britain - and subsequently increasingly of the market for the broadcasting rights for professional football, including for pay-TV in the form of both subscription channels and pay-per-view on an individual match basis - have thus been purposively constructed. Over time, it has also been deliberately changed, significantly, under the influence of internal and external pressures on the game. This has taken the form of the richer clubs breaking away from the existing league structure to create their own 'Premier' league. It has seen media companies buying into football clubs, most dramatically with the attempted merger between Manchester United and BSkyB. And as discussed below, the Office of Fair Trading (OFT) tried and failed to break up the collective selling arrangements by the leagues to media companies.

This chapter analyses the economic and policy implications of three interrelated aspects of the corporate governance and regulation of professional league football that underlie these changing institutional arrangements: first, changes in ownership structures and corporate governance; second, vertical integration between broadcasting companies and football clubs; and third, the collectivity of football leagues and the sale of broadcasting rights. The next section deals with issues of corporate governance and argues that fan equity should be recognised as 'goodwill' in clubs' accounts and that supportershareholder trusts should be formed to solve the problem of misaligned incentives and the associated principal-agent problems between supporter shareholders and commercial investors. The third section deals with issues of vertical integration between football clubs and broadcasters, while the fourth looks at the welfare implications of league collectivity and the exclusivity of broadcasting rights. The final section draws some conclusions and argues that the three factors comprising the 'peculiar economics of football' require a dual system of regulation: regulation from below to resolve problems of corporate governance and misaligned incentives and regulation from above to prevent distortions of the competition in broadcasting and preserve the collectivity of the leagues. 


\section{Corporate governance}

There is now a growing recognition that match-going fans are intrinsically involved in the joint production of football matches. Crowd involvement and support can add greatly to the entertainment value of matches, and a match played before a packed stadium is more enjoyable and provides more qualityadjusted units of output than one played in front of empty seats. This is particularly the case for matches that are screened live, where the crowd adds greatly to the audio-visual content of the programme. For that reason, together with the considerations that football supporters, unlike almost any other industry's customers, are unlikely to switch allegiances or brands no matter how sub-standard the product. Football supporters are clearly stakeholders in their clubs. This particular form of stakeholding has been termed 'fan equity', (see Hamil 1999 for a discussion of this notion). Of course, it is difficult to estimate the economic value of 'fan equity', but the problem of valuation here is no different from the standard problem facing companies which regularly put a value on 'goodwill' in their annual accounts. Moreover, there have been numerous cases where the extent of fan equity has had clear monetary dimensions. For example, many clubs faced with bankruptcy have turned to their fans for financial support to keep the clubs up and running. Plainly, there are few industries where the customers would organise a whipround to prevent a company from closing. Recognising fans as stakeholders in this way means that issues of corporate governance take on particular dimensions (as discussed below) and regulatory implications.

The change in corporate governance structures that has occurred as clubs have been transformed into plcs raises particular issues in the case of professional league sports. In particular, it is evident that institutional investors in football clubs may have very different objectives from those of supporter shareholders. Unlike the latter, institutional investors do not contribute directly to the joint production of the product. At the same time institutional shareholders are not subject to the kind of brand loyalty that makes them peculiarly vulnerable to exploitation of local monopoly power. This implies that there is an incentive for financial and institutional shareholders to exploit brand loyalty and local monopoly at the expense of supporter shareholders. Finally, the stockmarket flotation of football clubs has allowed supporters and media companies to acquire significant ownership stakes in leading clubs. However, the interests of these two groups of shareholders are often diametrically opposed. For example, media companies may have an interest in the formation of a European 'Super League' as a means of maximising pay-TV (satellite and cable) subscribers in the European marketplace, while supporters have an interest in maintaining national leagues as the main competitive arenas.

The Government set up the Football Task Force to investigate these corporate governance issues, and its unanimously approved third report (Football Task Force, 1999) supported the formation of supporter-shareholder trusts. 
The resulting formation of Supporters Direct aims not only to assist the formation of such trusts, but also has the declared aim of encouraging the election of representatives of such trusts to the boards of directors of football clubs. ${ }^{3}$

\section{Vertical integration}

The arguments in this section are illustrated by reference to the issues raised by BSkyB's attempted take-over of Manchester United. In September 1998 British Sky Broadcasting Group made a formal offer to acquire Manchester United. The bid, which amounted to an attempt by Britain's dominant payTV sports broadcaster to control Britain's leading football club, rang warning bells among BSkyB's competitors and Manchester United's shareholders and fans. The former feared that the take-over would consolidate BSkyB's already dominant position in the market for live football broadcasting and make it even more difficult for others to make inroads into the industry. The latter felt that Manchester United's interests would become subservient to BSkyB's broadcasting interests, as the club would become a bargaining and marketing tool for a broadcasting company intent on enhancing its dominant position in the pay-TV market. The director general of Fair Trading agreed that both the fans and BSkyB's competitors were right to be worried, and on 29 October 1998 he referred BSkyB's proposed acquisition of Manchester United to the Monopolies and Mergers Commission (MMC) for investigation under the Fair Trading Act 1973.

The MMC was charged with the task of investigating the proposed acquisition and determining whether it might be expected to operate against the public interest. It is normal for the MMC to consider public interest concerns but unusual for the OFT to require this in the referral. This unusual step no doubt reflected the unprecedented number of submissions, received by the OFT, overwhelmingly opposed to the take-over. The MMC set up a panel of five experts drawn from the members of the Commission, chaired by Dr Derek Morris, the overall chairman of the MMC. During the next four-and-a-half months, the panel investigated the proposed acquisition, taking evidence from over 350 parties.

On 12 March 1999, the MMC delivered its findings in a report to the secretary of state for Trade and Industry (Monopolies and Mergers Commission, 1999). Four weeks later, on 9 April 1999, Stephen Byers, secretary of state for Trade and Industry announced his decision to block BSkyB's proposed acquisition of Manchester United based on the basis of a full acceptance of the findings of the MMC. In his announcement to the Stock Exchange Mr Byers said:

Having considered the [MMC's] report, advice from the Director General of Fair Trading and also taking into account further representations which have been received, I have decided to accept in full the unanimous recommendations of the MMC. The MMC's findings are based mainly on competition grounds, where they concluded that the merger would adversely affect competition 
between broadcasters. But they also examined wider public interest issues, concluding that the merger would damage the quality of British football. I accept these findings. (Department of Trade and Industry, 1999)

In this section we outline and assess the issues raised by the BSkyBManchester United case and discuss their implications for the future of British football. We start by considering the nature of the footballing industry. An appreciation of this, and of the peculiar 'brand loyalty' of the consumers (fans), is important to a proper understanding of the effect that the acquisition of football clubs by broadcasting companies would have on the public interest. We then analyse the anti-competitive effects that the attempted acquisition would have had on the broadcasting and media markets, before going on to consider broader public interest concerns relating to the quality of British football. ${ }^{4}$

\section{The nature of the football industry}

The nature of the British footballing industry, with its local and community involvement, and its fan loyalty, creates public interest concerns and also makes the industry peculiarly vulnerable to anti-competitive behaviour. Before detailing the grounds on which the attempted acquisition of Manchester United by BSkyB would have acted against the public interest it is important to appreciate, firstly, the unique nature of the industry; secondly, the rather different notion of the 'firm' that is appropriate to an analysis of this industry than is the case when analysing most other industries; and, thirdly, the peculiarities of this industry's customers - the football fans.

Firstly, regarding the nature of the football industry, while it has become fashionable to refer to the range of stakeholders that a firm or industry has beyond its shareholders, in the case of football the importance of those other stakeholders - and in particular of the local communities - is absolutely vital. ${ }^{5}$ While anti-competitive practices should be opposed whatever the industry, the precise way in which such practices operate varies from industry to industry, and so an appreciation of the impact of these practices in the case of the acquisition of a football club by a media company is assisted when the nature of the footballing industry is understood.

Secondly, regarding the 'firms' involved in the industry, the importance of the football club to the local community - and conversely the importance of the local community as a key stakeholder in the football club - has been reflected in the fact that the firms which own and control football clubs have generally been dedicated to this task. There are of course football-related activities in addition to the operation of the actual football club, but this does not detract from the fact that the main line of business of the firm is not with the media or other interests but, rather, the football club. Also, while wealthy individuals have often bought football clubs, those individuals have tended to be supporters of that club, and have not used the club to promote their own business operations to the disadvantage of other firms competing in whatever markets their own business operates. 
Thirdly, as Hamil (1999) argues, the relation of the customer - in this case, football fans - to the product and hence to the company, is rather different from that which obtains in other industries. In most industries, if a firm's product is not sufficiently competitive in terms of price and other factors, consumers will be lost to rival firms. In the case of football, the customers tend not to switch allegiances so easily (either between clubs or sports). This creates a situation analogous to one of local monopoly, discussed below. It is true that fans can continue to support the club and may be able to consume the product through pay-TV (currently, in the UK, by subscribing to BSkyB which holds the exclusive rights for broadcasting Premiership matches live), rather than paying through the turnstile at the ground. But that is a rather limited form of competition, since it does not involve the consumer switching from one team to another, and even this limited degree of competition between outlets would have been eliminated entirely in the case of Manchester United if the attempted acquisition had been allowed to proceed. The special nature of the footballing industry thus both creates particular public interest concerns and influences the way in which specific restrictions on competition operate in that market. The particular and peculiar nature of the footballing industry, and the concomitant necessity for regulatory intervention, have long been recognised. It led, for example, to the Football Association's rule 34 which aimed to prevent the commercial exploitation of clubs, ${ }^{6}$ and more recently to the establishment by the Government of the Football Task Force.

The peculiar nature of the footballing industry can be illustrated, finally, by reference to one of the consequences which the attempted acquisition would have had - which has not, as far as we are aware, been commented on to date in public discussion - namely that several thousand shareholders who have a keen and passionate interest in the future success of the company in which they have a stake (as owners as well as supporters) would be forced by law, against their will, to part with their shares. This is a rather dramatic reversal of the whole impetus of governmental policy over several years now, across both Conservative and Labour Governments, to encourage wider share ownership. Indeed, one of the main arguments used in favour of floating Manchester United Football Club as a plc was precisely to encourage wider share ownership. BSkyB made clear that their aim was to acquire the 90 per cent of shares which would have allowed them, by force of law, to require all remaining shareholders - which in the case of Manchester United plc consists of several thousand fans - to then part with their shares in their club. As one shareholder put it at the November 1998 Manchester United plc AGM, his share certificate is displayed proudly on his wall at home; had the acquisition proceeded, he would not have replaced it with a share certificate in BSkyB.

Anti-competitive threats and restrictions on competition

BSkyB's bid raised three separate areas of concern regarding anti-competitive threats and restrictions on competition: 
The market for watching Manchester United There is a large market for watching Manchester United. This market is part of the wider market for watching football, which in turn is part of the general market for watching sport, itself a part of the broader market for entertainment. While there are therefore related and segmented markets, there is no doubt that there is a distinct market for watching Manchester United, for which a match between, say, Coventry and Wimbledon (two other Premiership clubs) is not a close substitute. There are two outlets for this market for watching Manchester United - either attending the ground or else watching games live on television. The sales via these two outlets are organised and priced by separate companies, namely Manchester United and BSkyB respectively. Had the attempted acquisition been successful it would have created a monopoly provider for the two outlets. This would have resulted in at least two anti-competitive threats.

Firstly, the monopoly provider would be able to decide on price rises for the two outlets simultaneously. And although as with any monopolist there would be a point beyond which price rises became unprofitable, the monopoly provider would no longer be as concerned as would a non-monopoly provider, at the prospect of a price rise shifting some customers to the other outlet, of watching on television. The welfare effects of vertical integration and vertical mergers are normally judged on a case-by-case basis. In contrast to horizontal mergers the impact of vertical mergers on economic welfare depends on the nature of the vertical relationship between the two companies. Vertical merger between two companies that are producing complementary goods is unlikely to be welfare decreasing, in the sense that raising the price in one part of the company will be offset by a fall in demand not only in that industry but also in the complementary industry. In substitute industries vertical mergers can have more serious adverse effects because an increase in price in one segment of the market will lead to an increase in demand in the firm's other market segments. In effect, the vertically integrated company is able to use price increases in one market as a means of raising demand in its related substitute market.

Secondly, there would have been a wider danger of this restriction on competition leading to an abuse of the resulting market power, with behaviour detrimental to the interests of attending fans, such as altering the day of the week and the time of day when matches are staged. ${ }^{7}$ This is already done to some extent, in the interests of maximising viewing figures, but at least there is a strong countervailing force with the interests of the attending fans being represented by a company (Manchester United) separate from the broadcaster.

Anti-competitive practices and restrictions on competition BSkyB has a huge financial interest in its televising of live Premiership football. The attempted acquisition would have weakened the competitive position of BSkyB's broadcasting rivals and would have strengthened BSkyB's already dominant position in pay-TV. The football club in question would have been owned by one of the 
broadcasting companies and would therefore inevitably have been used to distort the bargaining process, creating restrictions on competition.

If the attempted acquisition had proceeded, then, in any subsequent negotiations over the rights to televise football, there would have been a change in the balance between the TV company and the football clubs: BSkyB and its rival broadcasters would be on one side of the bargaining table, and on the other side would be the clubs, with BSkyB owning and representing the biggest and most powerful of those clubs.

It is the interest of all league football clubs to reach agreement with whichever broadcasting company offers the best deal. With the attempted acquisition, other broadcasting companies would have been put at a competitive disadvantage vis à vis BSkyB. Manchester United could have been used to push for an acceptance of the BSkyB offer. The club might have done this even if the deal had not been in the interests of the footballing industry taken as a whole, provided it was in the interests of its parent company, BSkyB.

Manchester United's vote - and more importantly, its power and influence - would have been used to favour a deal with BSkyB rather than with BSkyB's competitors. In addition to representing a distortion of the competitive process to the detriment of other broadcasting companies, such a situation could also have posed an anti-competitive threat to other football clubs in the Premiership (and might in addition have had a deleterious effect on clubs outside the Premiership). If the merger had gone ahead and the Restrictive Practices Court had ended the current bargaining arrangements, then other broadcasters would have been at a competitive disadvantage vis à vis $\mathrm{BSkyB}$ in attempting to secure television rights, since the biggest and most popular club would already be owned by one of the other broadcasting companies. This would no doubt have provoked those other broadcasters to buy up top football clubs themselves. Whether the BBC would have been permitted to defend itself in this way is, however, rather to be doubted. Nor would such a defense of the BBC's interests be something to be welcomed; on the contrary, it would replicate many of the anti-competitive dangers described in this section, and would further divide the Premiership between the few top clubs, on the one hand, and the rest of the league, on the other.

In addition, the position of other football clubs vis à vis BSkyB would have been affected by BSkyB's ownership of one of the clubs. Had the attempted acquisition been reported as Manchester United acquiring BSkyB, objections would no doubt have been raised by the other clubs that the main broadcaster was to be owned by a Premiership club. BSkyB ('owned' under this scenario by Manchester United) would even have the right to move the dates and times of crucial games to be played by Manchester United's rivals in the title race. This is just one of the more minor ways in which vertical integration between a broadcaster and a football club could be abused, to the more general implications of which we now turn. 
Abuse of vertical integration The attempted acquisition would have decreased competition through the vertical integration of the supplier (Manchester United) and broadcaster (BSkyB) of Manchester United football matches. In the event of Premier League clubs individually negotiating television rights, Manchester United would then find itself 'negotiating' with its owners a most extreme case of exclusive trading. There is reason to be concerned that such vertical integration may even have operated against the interests of Manchester United itself. If BSkyB were to require the participation of Manchester United to launch a European Super League, or any other such venture, there would be a risk that the club would be forced by its parent company to break away from the Premiership, if that was what was required to accomplish the parent company's media goals. ${ }^{8}$

The vertical integration of BSkyB and Manchester United would have created three additional anti-competitive threats.

Firstly, in 2001 when the other broadcasters had to compete with BSkyB over the rights to televise live Premiership matches, BSkyB would have been in a position to offer more than its rivals, since a proportion of BSkyB's offer would have returned directly to the vertically integrated company. The proportion of the money that would have returned to BSkyB, via its ownership of Manchester United, would have been far greater than 5 per cent, ${ }^{9}$ as matches involving Manchester United are shown more frequently and attract more viewers than matches involving many other Premiership clubs.

Secondly, such vertical integration would risk the natural competitive processes in both industries - broadcasting and football - being distorted through cross-subsidies. The likely direction would be for the broadcaster to cross-subsidise the football club, since the competitive advantage this would give the football club against the competitor clubs would be expected to produce a subsequent pay-off to the broadcaster, as success on the field led to increased viewing figures, including through pay-TV. ${ }^{10}$ Such cross-subsidising would lead to a growing inequality and competitive imbalance; these effects would have been intensified had the BSkyB bid proceeded, and would subsequently have triggered other bids by broadcasters for Premier League clubs. There is also the possibility that the crosssubsidising danger would work the other way, with the broadcaster using profits from the football club to allow BSkyB to undercut its rival TV companies for a time.

Thirdly, the attempted acquisition would have represented a form of vertical foreclosure, thus impeding competition. The market for football broadcasting and packaging is increasingly a market for ideas in which diversity and creativity matter. Such a market is best served by being fragmented, allowing new entrants to innovate and compete. Vertical integration restricts such processes. Indeed, the attempted acquisition would have been a move against the trend, deliberately promoted by Government, to encourage outsourcing from broadcasters to other content providers. 
Public interest concerns and the quality of football

The bid by BSkyB to acquire Manchester United represented a serious threat to the interests of British football both as a leisure activity and as a business sector. It is important to maintain - and indeed strengthen - the current links between the various sectors of the footballing industry. The majority of Premiership players start their careers in the lower divisions, including nonleague clubs. The majority also finish their footballing careers outside of the Premiership, either as players, managers, or in some other football-related occupation. There are therefore strong bonds within the game. These links are vital to the continued health of the sector, and in the long term even to the success of individual Premiership clubs despite the fact that over the short and medium term their profitability could be boosted by neglecting such links.

It is important to stress two points here. Firstly, rich individuals have in the past bought clubs, and clubs have also been floated as plcs. The attempted acquisition of Manchester United was quite different from all previous takeovers or flotations, in that it would have left the football club as only a small part of the parent company's operations; in addition, the main interest of that parent company (BSkyB) - namely broadcasting - would be other than football, and yet at the same time there would have been a strong incentive to use the footballing part of the business in the interests of the parent company. The link between this football club and other clubs in England would have become, at best, less important in the eyes of the relevant-BSkyB-shareholders.

Secondly, the attempted acquisition should not be considered in isolation. Had this acquisition been allowed to proceed, it is likely that similar takeovers of other major Premiership clubs would have followed. Such a process would have been inimical to the long-term development of the game as a whole. It could even have led to a formal breakaway of such 'super clubs' from the rest.

There is also the local monopoly aspect of football clubs that needs to be taken into account. Football fans almost invariably support only one team, and this support is translated commercially through attendance at matches and watching or listening to them through TV and radio, and through purchasing associated goods and services. Such consumers (fans) do not readily switch their consumption to another football club. Support and loyalty creates a lock-in to one club. Thus, the owners of football clubs are, in effect, local monopoly suppliers of a unique product, and that raises major regulatory concerns. There have been various factors preventing the abuse of this monopoly power in the past, including the FA's rule 34, referred to below. The success of the attempted acquisition would have constituted a serious risk that this monopoly power would be exploited against the public interest.

A couple of additional comments are called for in relation to the claim that each club is to a large extent a local monopoly. As mentioned above, this is due to the nature of football support, with clubs relying on local support and this in turn resulting in fan loyalty to the local club. This monopoly power derives both from geographical locality and from the nature of fan loyalty. ${ }^{11}$ 
In other sectors of the economy (such as the water industry) such local monopoly would be seen as sufficient reason for direct regulation. In the case of the footballing industry this has not, to date, proved necessary as there has been a general recognition both of the above facts and also, therefore, of the importance of not over-exploiting this monopoly power. There is serious reason to doubt whether BSkyB would have exhibited the same degree of self-restraint. ${ }^{12}$ There was thus good reason to suspect that an abuse of monopoly power would have resulted. As indicated above, the attempted acquisition would have diminished what restraining influences there are at present, such as the choice between attendance at the ground, on the one hand, and paying for a BSkyB subscription to watch Premiership games live on television, on the other.

\section{The MMC's findings}

The MMC broadly accepted the points made above, and recommended against the merger, a recommendation that the Government accepted. In announcing his decision, the secretary of state for Trade and Industry stated that

the proposed merger may be expected to reduce competition for the broadcasting rights to Premier League matches. This would lead to less choice for the Premier League and less scope for innovation in the broadcasting of Premier League football. The MMC also concluded that enhancing BSkyB's ability to secure rights to Premier League matches in the future would reduce competition in the market for sports premium television channels. This would in turn feed through into reduced competition in the wider pay TV market. ${ }^{13}$

On the question of wider public interest concerns, the Commission concluded that the merger would adversely affect football:

We have concluded that the merger would reinforce the existing trend towards greater inequality of wealth between clubs, weakening the smaller ones. We have also concluded that the merger would give BSkyB additional influence over Premier League decisions relating to the organisation of football. On both counts the merger may be expected to have the adverse effect that the quality of English football would be damaged. This adverse effect would be more pronounced if the merger precipitated other mergers between broadcasters and Premier League clubs. (Monopolies and Mergers Commission, 1999)

\section{Summary}

BSkyB's attempted take-over of Manchester United plc would have strengthened BSkyB's dominant position in broadcasting. (Matches involving Manchester United account for 25 per cent of all BSkyB's viewers of Premier League matches.) Vertical integration between broadcasters and football clubs raises a number of issues surrounding competition and vertical restraints. In particular, vertical integration may

- distort the bargaining process for the sale of TV rights;

- facilitate market foreclosure in broadcasting; 
- lead to greater exploitation of the local monopoly that clubs enjoy; and

- widen the inequality between the leading clubs and the rest.

The secretary of state's decision to block the merger may have deterred other broadcasters from attempting to take over football clubs but it has not stopped a number of media companies (including BSkyB) from acquiring vertical shareholdings in leading Premier League clubs. This goes against the arguments set out in the MMC's report ${ }^{14}$ and raises the question of whether such vertical linkages should be prohibited in the case of football clubs and broadcasting companies, as they have been in a number of other industries, such as rail, gas and electricity.

\section{League collectivity and broadcasting rights}

The emergence of football as the main programming 'software' used to attract viewers in the pay-TV market has led to regulatory concerns over vertical integration between football clubs and broadcasters, as well as over the role of leagues as collective suppliers of live broadcasting rights. These two concerns have been the subject of a case brought before the Restrictive Practices Court (RPC) by the OFT against the Premier League over the latter's collective sale of television rights, and of a Monopolies and Mergers Commission inquiry, which recommended the blocking of the proposed vertical merger between BSkyB and Manchester United plc. The central issues underlying these cases are closely linked. The OFT's case against the Premier League's collective sale of television rights rested on the argument that the League was behaving like a cartel, raising prices and restricting output. This failed to appreciate the importance of the collectivity of the League and the fact that it serves at least two functions. First, unlike a standard price-fixing cartel, which contributes nothing to the product sold, it is actively involved in the joint production of the output. Second, the League plays a functional role by regulating the inherent tendency for imbalance by the redistribution of television revenues from the more successful clubs downwards. This may be compared with a situation of individual selling by clubs where the leading clubs would be able to charge considerably more than the lagging clubs for the TV rights to their matches because they attract more viewers per match. It was largely on those grounds that the RPC judgement went against the OFT. ${ }^{15}$

\section{Conclusions}

This chapter has identified three peculiarities of the economics of professional football. This triad of peculiarities suggests the need for multiple forms of regulation. Incentive conflicts between clubs, and between clubs and their league (where leading clubs can credibly threaten to leave to form a rival league) undermine the capacity of leagues, particularly the Premier League, to be selfregulating and suggest the need for an independent regulator. Incentives for 
vertical integration between clubs and broadcasters serve to distort competition in broadcasting, threaten the collectivity of the league and may adversely affect the quality and organisation of football. There is a clear need to prevent such vertical integration, as is the case in industries, such as rail, electricity and gas. Finally, stakeholder conflicts brought about by the stock market flotation of clubs may be resolved, or at least alleviated, by the formation of shareholder/supporter trust holdings. What is required is a dual system of regulation with top-down regulation to preserve league collectivity and distortions of competition in broadcasting and bottom-up regulation to resolve corporate governance issues.

\section{Notes}

1 We are grateful to Jeanette Findlay, Sean Hamil and Bill Holahan for valuable comments and discussion. The usual disclaimer applies.

2 For a report on the state of corporate governance at football clubs, see Hamil, Michie, Oughton and Shailer (2001).

3 For a description of the origins and operation of Supporters Direct, see the various contributors to Hamil, Michie, Oughton and Warby (2001).

4 This section draws on our submission to the MMC made jointly with Keith Cowling, Simon Deakin, Laurence Harris, Michael Kitson, J. Stan Metcalfe, Malcolm Sawyer, Ajit Singh and Roger Sugden, to whom we are grateful. We are grateful to Gordon Borrie, Sean Hamil, Alan Hughes and Geoffrey Whittington for advising on the drafting of the submission.

5 In the 1992 Fulham FC v. Cabra Estates plc case the Court of Appeal expressed the view that the company (Fulham FC) was more than the sum of its 'members' (i.e. shareholders), and on that basis blocked the sale of the football club's ground.

6 Rule 34 is discussed below.

7 This would be particularly detrimental to travelling fans who might have already made travel arrangements, including the purchase of flight or rail tickets which may be wholly or in part non-refundable.

8 In 1998 the Premiership did threaten, Manchester United and the other clubs involved with expulsion from the Premiership over their discussions regarding a European Super League (discussions which Manchester United had denied they were involved in, although this denial turned out to be false).

9 Five per cent, since Manchester United is one of twenty clubs in the Premiership.

10 Such cross-subsidisation would have implications quite different from the case where money is put into a football club by, for example, a benefactor; in the case of the attempted acquisition of Manchester United by BSkyB a cross-subsidising of Manchester United might have been pursued not just to favour Manchester United against other football teams, but because this would have then given $\mathrm{BSkyB}$ an advantage over the other broadcasting companies.

11 Gerry Boon of accountants Deloitte and Touche has refered to the demand inelasticity from this brand loyalty: 'That means you can put the prices up but the demand doesn't change. They still buy the product.' (cited in Conn, 1997, p. 155). Manchester United could probably continue to sell all tickets - even on an advanced season ticket basis - for all home games even if they increased prices 
substantially. Indeed, average admission price increases of over 30 per cent were introduced for the 1991-92 season (Manchester United plc Prospectus, 1991).

12 Price wars involving The Times and The Sun, and between Sky and BSB, were pursued aggressively.

13 Department of Trade and Industry (1999), p. 2.

14 As argued by Nicholas Finney, OBE, MMC panel member for the BSkyBManchester United inquiry; see Finney (2000).

15 The peculiarity of the economics of sports leagues is perhaps illustrated by the fact that this was the first time the Office of Fair Trading has ever lost a case in the Restrictive Practices Court.

\section{References}

Conn, D. (1997), The Football Business, Edinburgh, Mainstream Publishing.

Department of Trade and Industry (1999), Press Release: Stephen Byers Blocks BSkyB/Manchester United Merger, London, DTI.

Findlay, J., Holahan, W. and Oughton, C. (1999), 'Revenue sharing from broadcasting football', in Hamil, S., Michie, J. and Oughton, C. (eds), A Game of Two Halves? The Business of Football, Edinburgh, Mainstream Publishing, pp. 124-38.

Finney, N. (2000), 'MMC's inquiry into BSkyB's merger with Manchester United plc', in Hamil, S., Michie, J., Oughton, C. and Warby, S. (eds), Football in the Digital Age: Whose Game is it Anyway?, Edinburgh, Mainstream Publishing, pp. 79-80.

Hamil, S. (1999), 'A whole new ball game? Why football needs a regulator', in Hamil, S., Michie, J. and Oughton, C. (eds), A Game of Two Halves? The Business of Football, Edinburgh, Mainstream Publishing, pp. 23-39.

Hamil, S., Michie, J., Oughton, C. and Shailer, L. (2001), The State of the Game: The Corporate Governance of Football Clubs 2001, Research Paper, No. 2001/02, Football Governance Research Centre, Birkbeck, University of London.

Hamil, S., Michie, J., Oughton, C. and Warby, S. (eds) (2001), The Changing Face of the Football Business: Supporters Direct, London, Frank Cass.

Monopolies and Mergers Commission (1999), British Sky Broadcasting Group plc and Manchester United PLC: A Report on the Proposed Merger, Cm. 4305, London, Stationery Office.

Neale, W. (1964), 'The peculiar economics of professional sports', Quarterly Journal of Economics, 78(1), pp. 1-14. 